\title{
Te matauranga o ko wai au
}

\author{
Karl Pearce
}

\author{
Ko Wai Au? \\ Ko Whakatere te Maunga, \\ Ko Waima te Awa, \\ Ko Rahiri te Tangata, \\ Ko Whakaruru te Waka, \\ Ko Ngapuhi te Iwi, \\ Ko Te Mahurihuri me Ngati Hurihanga Nga Hapu, \\ Ko Wharerau Whanau whakapapa Maori au, \\ Ko Hamana Wharerau oku Koro, \\ Ko Judy Wharerau oku Whaia, \\ Ko Don Pearce oku Matua, \\ Ko Karl Pearce taku Ingoa, \\ Ko Braden Crombie taku Tama.
}

Whoo aye! Being able to mihi my pipiha is a result of several years' research beginning with choosing to attend Massey University in 2002. Until then I saw myself as a New Zealand European who happened to tan easy and have some Maori relatives. Then I had no idea my worldview would be turned upside down, yes my worldview sure has changed! But why did my worldview change?

Attending Massey University has enabled me to access new information, which I would not have otherwise known was available. This has enabled me to critique my childhood upbringing, education, ignorance and biases. During my time at Massey I have seen the effects of the Owera speech by Dr. Don Brash, the then leader of the National Party 20032006 titled Nationhood delivered on 27 January 2004, a derivist piece of work which scaringly resulted in his subsequent rise in popularity, especially among white middle New Zealand. On the 5th May 2004, I and a group of students from both Massey and Victoria universities joined the march on Parliament against the Foreshore and Seabed legislation. Helen Clark, the then Prime Minister decided to see an overly grown sheep called Shrek rather than face 10,000 people, most Maori, on parliament grounds, all because of an act which took away the rights of a hapu in Nelson to their day in court, plus it extinguished my sons' rights to customary fishing in Northland due to me being urban Maori. I have seen and heard the effects of clearly institutional racist decisions made during the October 15th 2007 'terrorist raids' on a small town in Ruatoki, Tuhoe country. I believe these acts being accepted by the majority of New Zealanders has much to do with the education, or mis-education, by most public schools which includes historically amnesiac accounts of the signing of the Treaty of Waitangi and the subsequent 'Maori Land Wars' (the name of which has connotations of it being Maori wars). However, many history schoolteachers today are embracing, and teaching, the revised and de-colonised history of Aotearoa New Zealand including the 'New Zealand Wars'.

Educational government policies, particularly the 1867 Native Schools Act (Durie, 2001; King, 2003; Rice, 1992), gave provision for Maori education to accelerate assimilation into 
western culture. Also the 1907 Suppression of Tohunga Act outlawed Tohunga passing on spiritual and educational teachings (Durie, 2001). These and many other Acts meant that my grandparents had their Maoriness forced from them by an education system (Native Schools) bent on making them English. Examples of this within my whanau are my grandfather, my mother's father, being born Hamana Wharerau, but I only ever knew him as Sam. This is also true of his father, my great-grandfather, who was born Panikera Aperahama Wharerau, however he was only known as Ben. My Great Aunt Miritiana, who passed on to me this information, remembers getting rapped across the knuckles at school as a child for speaking her native tongue in class (M. Davis, personal communication, 2003). She too was forced to take on a Pakeha name, Mary, which she used for many years until she decided that she no longer had to be bound by a name used to enslave her, so she reverted back to her birth name, Miritiana. My grandfather, however, did not, and continued to use Sam up until the day he died, and subsequently Sam is used on his gravestone. Sadly, we still use this form of name change with immigrants and students from Asian nations, who are 'encouraged' to take on English names upon entry into our country. Yet again, an insidious form of colonisation, elitism and just plain laziness on our behalf.

As with all education it begins in the home. My mother grew up in Waima and was the eldest child, having a Maori father and a Scottish/Pakeha mother. She grew up in the Jehovah's Witness religion, which is based in North America and has strong Northern American-centric ideologies. Because of my grandfather's Native School education and grandmother's strong religious convictions my mother, whilst understanding te reo Maori, speaks very little. Recently she has spoken more, since my younger sister, Eva, and myself have shown interest. She grew up with a strong Euro-centric worldview within home and school, however, I believe Waima itself would have provided many insights into a Maori way of life and she would not have been totally devoid of things Maori. For my mother, Waima was a small town with limited opportunities and, like many young Maori at the time, she moved to the city, where she was able to successfully expend things Maori and navigate her way in the Pakeha culture.

My father was brought up in Christchurch and later Westport where he tells me he doesn't remember seeing many Maori, and of those his memory is hazy. My father's real dealings with Maori first came in his twenties when he moved up to the North Island, where he recalls he had never known so many Maori in one place. My father's public school education consisted of the usual biased account of the signing of the Treaty of Waitangi (not Te Tiriti O Waitangi) and subsequent Maori Land Wars and how Maori ate all the Moriori. Reading Michael King's Penguin History of New Zealand proved insightful to my father, yet his early learning still hampered his belief in some historical aspects of King's book.

The reason for this short and, my parents would say very limited, account of their upbringing, is because the impact of socialisation, interpretation of history, their educational experiences and held beliefs acquired by them, impacted not only on my early life, but also on what I consider to be my future direction as a practising social and community work practitioner, who is both male and Maori in Aotearoa New Zealand.

So little Karl was brought up unknowing his Maoritanga. I was brought up Pakeha, if you like, an easily tanned Pakeha boy not different at all to my mainly white friends (I also had two Indian friends). And because it was my father who was white and upper working 
class, I was able to successfully be Pakeha in a rural farming New Zealand town. With this brought positive aspects, for I do have many fond memories, as well as the ignorance and prejudice that growing up in a small rural town brings.

At Woodville School I remember the only language that I was taught was English. The only Maori I learnt was tahi, rua, toru, wha and Oma Rapiti (humorously when I first submitted this piece to Dr Leland Ruwhiu, I had spelt Oma Rapiti incorrectly), and, strangely, the song Sailing Away in both English and Maori! Our history lessons consisted mainly of English Elizabethan history, and the historically amnesiac account of New Zealand history. This consisted of an abridged version of the signing of the Treaty of Waitangi, with the accompanying Marcus King painting, Signing of the Treaty of Waitangi, of Hobson in all his Royal Naval finery, with native Maori naked or wearing piupiu and sitting on the ground. Sadly the Government still uses that painting today on their Treaty of Waitangi website. Another version of history was how these naughty native savages, particularly Hone Heke (pronounced Hoenee Heekee) kept defying the respectable government by continually cutting down the flagpole with our fine flag waving high on it (I assumed it was the New Zealand flag, no one said otherwise). I was later to learn, because of the Massey University Bachelor of Social Work (BSW) degree, that it was cut down four times, the first time by Hone Heke's second in command, Te Haratua, and the other three by Heke himself. Also omitted was that the flagpole was gifted by Heke to fly the 'Confederation of Tribes' flag, however, the British used it instead to fly the Union Jack (Orange, 2001; King, 2003); this is symbolic of colonialism at its worst. The fact that Hone Heke was a supporter of, and the first to sign, the Treaty was also omitted.

Throughout my primary school education there was little or no Maori content in my education. What I did learn in school about Maori was shaped in the school playground, as I saw Maori children with scruffy clothes, runny noses, and unkempt hair (in which I also assumed kooties ran rife). Looking back I thought myself quite superior.

There is a name for that...elitist.

Thinking about it, I must have been quite a condescending little boy. Little did I know, ignorant ones would say, of the historical and political ramifications that government policy had on my Maori peers. How lucky I was with a Pakeha father, I was able to escape the effects that a huge proportion of my Maori peers experienced during the economic and political upheavals of the 1980s.

So, my education and ignorance produced racism in me against my own whanau.

My mis-education and ignorance continued into college. I carried over most of the same friends from school, all white, non-Maori, many I knew from kindergarten, and my biases became more concrete. At Tararua College I saw an even greater divide between Maori and Pakeha. Sadly (I did not see it that way at the time) many Maori came from families with gang ties, bringing with them familial ideas and behaviours to school. This again made me resent Maori, hence my own Maoritanga even more as I felt it reflected upon me personally. In college at that time, as still today, the main language taught was English. In the third form English was compulsory, also the fourth form, with Maori and French respectively being compulsory within first and second terms, with the last term having a choice. In a previous assignment submitted to Dr Leland Ruwhiu, I wrote, 
Strangely we complained at having to learn Maori because we thought it was a useless and dying language .... and not useful internationally, we also complained about learning French too but (primarily) because the teacher was odd (we still felt French was useful) (Pearce, 2004).

However as Dr Ruwhiu pointed out this was a common argument (Ruwhiu, 2004). Later I was to learn, through my degree, that Maori is phonetically similar to many other languages worldwide, and studies show that bilingual children are advanced in seeing other people's worldviews, as well as picking up other languages (Bialystock, 1999, 2001; Bialystock \& Herman, 1999; Campbell \& Sais, 1995; cited in Berk, 2004). History again comprised of mostly a continuation of what I was taught in primary school with a historically amnesiac account of the Treaty of Waitangi and again the subsequent Maori Land Wars.

In my sixth form year my family and I moved to Rotorua. There I saw a completely different side to being Maori. I attended Western Heights High School where I was to experience seeing Maori as being proud of themselves, looking after themselves (as I saw it), and proficient in both Maori and English, able to navigate their way through both worlds successfully. I remember being very impressed and secretly jealous, however also thinking that by then I was too old to be bilingual myself. Ha, at the tender old age of 17 ! It was also at this time that I first met my only Maori grandparent, my grandfather, and to me he did not at all seem all that strange. He spoke very good English, had an English name (as stated earlier he went by the name Sam), and seemed to me fairly successfully retired. He was certainly my only link to things Maori, and he seemed quite normal. At this time also, I moved from a small town mentality, into a city where many more Maori lived and contributed to society. As well as meeting for the first time my link to the Maori in me, a dichotomy change began to occur, a life re-education had begun which at university would take fuller fruition. I was unknowingly being 'conscientised' (Freire, 1974) toward a place where I would be ready to explore my Maoritanga (Ruwhiu \& Ruwhiu, 2006).

I attended Massey University for many reasons. I had grown tired of ten-dollar an hour jobs; I had grown tired of having no real future; I was tired of getting drunk all the time. Also I had brought a beautiful child into this world and I wanted him to have a father he could look up to, a positive role model, and know that he, too, would be able to succeed in life. Little was I to know that university was to provide for me a new understanding of my Maoritanga, 'ko wai au', enabling me to explore another side of myself that I had no previous knowledge of how to explore or even that I could explore. The Massey BSW programme has enabled me to become open to the full and unbiased account of Aotearoa New Zealand history. I am fortunate to attend specific papers and lectures by leaders in their fields, by the names of Professor Mason Durie, Dr Leland Ruwhiu, Professor Robin Munford, Whiturangi Walsh-Tapiata, Associate Professor Christine Cheyne, Dr. Kieran O'Donoghue (I can name many more superpeople), who possess deeper and accurate sociopolitical understanding of Te Tiriti O Waitangi and the social work profession. I have been able to attend Hui Whakawhanaungatanga, which was a new experience for me. This was all part of my re-education. The hui was very foreign at first for me and I was totally out of my depth (I also realised at these hui that I use humour as a safety mechanism when in uncomfortable environments). I acted like a total arse at my first hui (if you can, ask Paule Ruwhiu), however it did help me in my journey towards conscientisation (Freire, 1974; Ruwhiu \& Ruwhiu, 2006) and I realised I was not alone in this journey but part of a much larger cohort. This was a particularly powerful discovery, and was a freeing experience knowing that I am not alone in this re-educating journey. 
Since coming to Massey University and beginning my journey through conscientisation (Freire, 1974; Ruwhiu \& Ruwhiu, 2006), I have new feelings and emotions regarding my Maoritanga. In the second year of this degree I began researching and found my mihimihi, which is at the beginning of this article, and discovered my whakapapa Maori of eight generations. In my fourth year, I made a totally remarkable discovery, through my mother, my whakapapa Maori back to Rahiri, through Kaharau. A whakapapa of 33 generations. Wow!

This journey has also enabled me to look at my Tangata Pasifika cousins (Mafile'o, 2001) and given me insights into their plights and historical situation. The same could also be said of our relatives from across the ditch, the 'dream time people' or, because Australians can not even be bothered giving them their correct name or even finding out what it is, 'Aboriginals'. Through my shocking, yet freeing, education I have met and made some wonderful friends whom some years ago I would have ignorantly thought beneath me. And is that not what conscientisation (Freire, 1974) or re-education is all about? Turning this ignorance we have been taught, or those we have picked up along the way, challenging those ignorances, and coming to new realisations about ' $k o$ wai $a u^{\prime}$. I have begun to understand who our tangata whenua, Tangata Pasifika, and Tauiwi bothers and sisters are, and that we are all created equal and have the right to pursue our Tino Rangatiratanga.

On the last day of the BSW, our class sat down and shared something that we each received from this degree, summing the four years we all spent together reaching this goal in our lives. I said that I had two things, 'I would not have reached the end of this journey with a different class and the new and lasting friendships I have made here' and 'this is only just the beginning!'

And it was! In re-writing this article for Te Komako, I have had to update some new information I have learnt since I first submitted it, for it is some years in the making now. I had to update some historical events, and of interest was the demise of Don Brash, the Foreshore and Seabed Act and hikoi, the 'terror raids' ordeal, Labour losing the 2008 Elections, John Key the new Prime Minister and the 'Super-city Maori seats' saga. When I started this article I thought my mother didn't speak any or little Maori, but I have since learnt that she is quite fluent, but doesn't use it as much as she might, and I have visited our whanau marae in Waima. I went up with two of my uncles, both now on their journey of self-discovery, and two great aunts whom I had never met before, who were in essence our guides. Of course my mother knew them all, but things Maori weren't important to me and my sister until now, so she just never mentioned them. I visited our whanau marae and urupa and received a history of my ancestors and how I connect to them. We visited our whanau marae which is mate, or dead, as it is currently used as a hay barn and a P-house, that saddened us that our whanau marae is in such a poor state. This has done one thing though, which is to bring our whanau together with a common vision to re-vitalise the marae. Uncles who I had not talked with in some years I am now in constant contact with, and we find similarities in our journey. My uncles and aunties feel they can pass on whanau knowledge, and seek it themselves with their rising confidence to mihi, and korero, and I am a part of that knowledge rennaissance lineage. We searched out and found the remains of my great ancestors' home, the original Wharerau, that he built before the land wars. We stood on the hill which overlooked Waima Awa, and over our marae which backs onto Whakatere maunga, the two major land connections in my pipiha, a pipiha that I had learned by heart and recited 
but until that day I had never forged or looked upon. That day I found my turagawaewae. I continue today to 'Te matauranga o ko wai au', this journey continues, who knows where it will take us next, for me what continues to be important in this journey is knowing that I am not alone, and many, many others share this story.

\section{References}

Bialystok, E. (1999). Cognitive complexity and attentional control in the bilingual mind. Child Development, 70, 3, 636-644.

Bialystok, E. (2001). Bilingualism in development: Language, literacy and cognition. Cambridge, UK; New York: Cambridge University Press.

Bialystok, E., \& Herman, J. (1999). Does bilingualism matter for early literacy? Bilingualism, 2, 1, 35-44.

Campbell, R., \& Sais, E. (1995). Accelerated metalinguistic (phonological) awareness in bilingual children. British Journal of Developmental Psychology, 13, 1, 61-68.

Durie, M. (2001). Te mana, te kawanatanga: The politics of Maori self-determination. Melbourne: Oxford University Press.

Freire, P. (1974). Pedagogy of the oppressed. New York: Continuum.

King, M. (2003). The Penguin history of New Zealand. Auckland: Penguin Books.

Mafile'o, T. (2001). Social work and the Pasifika dimension. In M. Nash, R. Munford, \& K. Hay (Eds.). Social work in context: Fields of practice in Aotearoa New Zealand (pp. 113-121). Palmerston North: Massey University.

Orange, C. (2001). The Treaty of Waitangi. Wellington: Bridget Williams Books Limited.

Pearce, K. (2004). Individual exercise: Personal and cultural development. Unpublished undergraduate assignment, Massey University, Palmerston North, New Zealand.

Rice, G. (ed). (1992). The Oxford history of New Zealand (2nd ed.). Melbourne: Oxford University Press.

Ruwhiu, P. \& Ruwhiu, L. (2006). Ko te pae o te atua mai I nga whakaaro hohonu nei, hei oranga mo te ira tangata. Te Komako, Social Work Review XVII(2).

Signing of the Treaty of Waitangi. www.nzhistory.net.nz/ media/ photo/ the-signing-of-the-treaty (Ministry for Culture and Heritage), updated 5-Sep-2007, Alexander Turnbull Library, Wellington, New Zealand Reference: G-821-2. 